\title{
PENGARUH STRUKTUR TEKS TERHADAP PENGUASAAN KONSEP DAN PENURUNAN MISKONSEPSI PADA LISTRIK DINAMIS
}

\author{
Gde Parie Perdana \\ Gandhi Memorial International School \\ Bali, Indonesia \\ E-mail: edgparie@gmail.com \\ Ketut Suma, \\ Ni Made Pujani \\ Universitas Pendidikan Ganesha \\ Bali, Indonesia
}

\begin{abstract}
Abstrak
Pengaruh Struktur Teks terhadap Penguasaan Konsep dan Penurunan Miskonsepsi pada Listrik Dinamis. Penelitian ini bertujuan untuk menganalisis pengaruh struktur teks yang digunakan pada materi pembelajaran terhadap penguasaan konsep dan penurunan miskonsepsi siswa. Penelitian menggunakan metode kuasi eksperimen dengan disain pre-test/post-test non-equivalent control group. Subjek penelitian terdiri dari 136 siswa kelas X SMA. Three-tier test dikembangkan untuk mengetahui konsepsi siswa. Terdapat dua kelompok eksperimen. Kelompok eksperimen pertama diberikan teks materi listrik dinamis dengan struktur teks perubahan konsepstual $(n=45)$ dan kelompok eksperimen kedua diberikan struktur teks sangkalan $(n=46)$. Kelompok kontrol $(n=45)$ diberikan teks materi listrik dinamis dengan struktur teks konvensional dengan struktur teks expositori. Analisis data menggunakan MANCOVA untuk mengetahuan pengaruh struktur teks terhadap kedua variable dependen dengan mengontrol pengetahuan awal siswa. Hasil penelitian menunjukkan siswa pada kelompok eksperimen mengalami peningkatan penguasaan konsep dan penurunan miskonsepsi yang signifikan dibandingkan dengan siswa pada kelompok kontrol. Semua kelompok mengalami peningkatan penguasaan konsep dan penurunan miskonsepsi, namun kelompok eksperimen menunjukkan hasil yang lebih baik.
\end{abstract}

Kata Kunci: struktur teks, teks perubahan konseptual, teks sangkalan, penguasaan konsep, miskonsepsi

\begin{abstract}
The Effect of Text Structure on Students' Understanding and Misconception Reduction of Dynamic Electricity. This study investigated the effect of text structure on student understanding and misconception reduction of dynamic electricity concept. A quasi-experimental research with pre-test/post-test non-equivalent control group design was used. The subjects for this study consisted of 136 tenth-grade students. The three-tier test was developed to access the student conceptions. There were two experimental group. The first experiment group received a text in conceptual change text structure $(n=45)$ and the second experimental group received a text in refutation text structure $(n=46)$. The control group $(n=45)$ received a conventional text in expository text structure. MANCOVA analysis was used in analysis data process to know the effect of text structure on both dependent variables by controlled the prior student's knowledge. The results of the study indicated that the student in the experimental group showed significantly higher understanding and higher misconceptions reduction compared to the students in the control group. All groups had increased understanding and misconceptions reduction, however, the experimental group's result was better than the control group.
\end{abstract}

Keyword: structur text, conceptual change text, refutation text, students understanding, misconception 



\section{PENDAHULUAN}

Setiap siswa memiliki konsepsinya sendiri. Konsepsi siswa tidak harnya berupa konsep ilmiah, tetapi juga berupa miskonsepsi. Miskonsepsi yang terjadi akan mengganggu proses pembentukan konsep baru. Hasil pre-test penelitian Ismail, Samsudin, Suhendi, and Kaniawati (2015) pada materi Listrik Dinamis, menunjukkan profil pemahaman konsep siswa hanya sebesar $13,9 \%$ dan profil miskonsepsi siswa sebesar $39,9 \%$. Ini menunjukkan penguasaan konsep pengetahuan IPA khususnya pada mata pelajaran fisika sangat rendah dan tingkat miskonsepsi siswa yang ditunjukan dalam penelitian ini tergolong tinggi.

Konsepsi siswa bersumber dari pengalaman pribadi yang dimiliki siswa, pengetahuan dan bahasa pengetahuan yang digunakan guru di kelas, dan buku teks yang dibaca oleh siswa (Gurel \& Eryilmaz, 2013). Buku teks pelajaran fisika umumnya dirancang dengan format konvensional yaitu teks dengan struktur ekspositori (expository text). Teks konvensional hanya memuat ensiklopedia pengetahuan dan belum mampu memberikan konflik konitif pada siswa, sehingga sulit merekonstruksi konsepsi siswa menjadi konsep ilmiah.

Guna mengatasi kelemahan teks konvensional, teks dapat dikembangkan dengan pendekatan perubahan konseptual yang menyebabkan konflik kognitif. Teks dikenal dengan teks perubahan konseptual atau conceptual change text (CCT) seperti yang dikembangkan oleh Posner, Strike, Hewson, and Gertzog (1982). Teks ini diharapkan dapat memperbaiki miskonsepsi yang terjadi pada siswa sehingga siswa dapat menguasi konsep yang dipelajari. Teks perubahan konseptual lebih efektif daripada teks konvensional dalam menata kembali skema konseptual siswa yang mengalami miskonsepsi (Akpınar \& Tan, 2011).

Pemahaman siswa terhadap suatu konsep tidak hanya disebabkan oleh teks yang terstruktur, tetapi juga bergantung pada pengetahuan awal siswa yang digunakan untuk menafsirkan konsep baru yang dipelajari. Tafsiran tersebut terlihat tidak berdasar, namun tafsiran tersebut lebih didasarkan atas akal sehat (common sense) bukan dengan pola pikir ilmiah. Pengalaman-pengalaman awal siswa yang memberikan tafsiran tidak sesuai dengan kaidah ilmiah tersebut dapat mengganggu proses pembentukan pengetahuan baru.

Perubahan konseptual diusulkan pertama kali oleh Posner et al. (1982). Perubahan konseptual didefinisikan sebagai suatu proses mental yang mana siswa dapat mengubah konsepsinya dengan jalan menambah pengetahuannya dengan konsep-konsep baru atau mengubah konsepsi awal yang telah dimiliki menjadi konsepsi ilmiah yang sesuai. Perubahan konseptual bertujuan untuk membantu siswa memahami konsepkonsep yang belum dipahami oleh siswa dan memperbaiki miskonsepsi siswa.

Perubahan konseptual terdiri dari dua fase yaitu asimilasi dan akomodasi (Posner et al., 1982). Fase asimilasi merupakan tahap dimana konsep yang dimiliki siswa tidak sepenuhnya memadai untuk memahami beberapa fenomena baru. Fase akomodasi merupakan tahap siswa harus mengganti atau mengatur ulang konsep utamanya. Selain kedua fase itu, dalam pendekatan perubahan konseptual suatu konsep membutuhkan empat tahap proses pemahaman agar dapat diterima oleh siswa yaitu: (1) dissatisfacation, (2) intelligible, (3) plausible, dan (4) fruitful (Posner et al., 1982).

Pada tingkat penguasaan konsep, siswa harus mampu mengorganisir dan menafsirkan diri telah belajar, artinya siswa dapat memvisualisasikan dan mengekspresikan dengan cara yang berbeda dan menggunakan kata-kata yang berbeda pada tiap informasi yang diberikan padanya Aydin (2012). Walaupun berbeda cara mengekspresikan informasi dalam proses pemahaman, konten informasi harus tetap sesuai dengan kaidah ilmiahnya.

Pandangan kontruktivisme mengakui adanya eksistensi pengetahuan awal yang dimiliki oleh siswa sebelum mengikuti pembelajaran di kelas. Siswa harus dipandang sebagai suatu subjek pembelajaran yang sudah memiliki pengetahuan awal sebelum mengikuti proses pembelajaran (Cordova, Sinatra, Jones, Taasoobshirazi, \& Lombardi, 2014).

Pengetahuan awal siswa sangat mendukung pembentukan konsep ilmiah pada diri siswa guna mencapai prestasi belajar. Sesuai dengan hasil penelitian Perdana (2017) bahwa pengetahuan awal berpengaruh signifikan terhadap prestasi belajar siswa. Tidak hanya mendukung, pengetahuan awal siswa juga dapat menjadi penghalang untuk belajar karena beberapa pengetahuan sebelumnya mungkin bertentangan dengan informasi yang akan dipelajari (Cordova et al., 2014). Oleh karena itu, mengetahui pengetahuan awal siswa menjadi langkah penting didalam proses belajar agar konsep yang diajarkan dapat dipahami oleh siswa.

Teks perubahan konseptual atau conceptual change text (CCT) adalah bahan pengajaran yang didasarkan pada pendekatan perubahan konseptual dan dirancang untuk memperbaiki miskonsepsi pada siswa (Ültay, Durukan, \& Ültay, 2015). Teks perubahan konseptual mengadopsi teori Posner et al. (1982). CCT dapat memberikan perubahan konseptual dan membuat perubahan konseptual yang terjadi pada siswa menjadi permanen (Guzzetti, Snyder, \& Glass, 1992). CCT juga dapat digunakan dalam program remedial. Teks perubahan konseptual lebih efektif daripada teks konvensional (expository text) dalam menata kembali skema konseptual siswa yang mengalami miskonsepsi (Akpinar \& Tan, 2011).

Komponen pada bagian perubahan konseptual dalam teks perubahan konseptual dapat diimplementasikan ke dalam teks konvensional. Struktur CCT terdiri dari 5 baian inti, yaitu (1) presentasi masalah, (2) miskonsepsi yang umum terjadi, (3) penjelasan dengan konsep saintifik, (4) opini siswa, dan (5) evaluasi (Ozkan \& Selcuk, 2015).

Teks sangkalan atau refutational text (RT) yang dirancang untuk pelaksanaan perubahan konseptual dapat memberikan pemahaman dalam membaca dan dalam membenahi miskonsepsi (Sinatra \& Broughton, 2011; Tippett, 2010). Penggunaan teks sangkalan pada pembelajaran fisika efektif dalam meningkatkan 
penguasaan konsep siswa dan dapat meningkatkan jumlah siswa yang memiliki konsep ilmiah (Ketut, 2016).

Pengembangan teks sangkalan dapat dilakukan dengan memodifiksi teks konvensional (teks ekspositori), dengan cara memperkayanya dengan paparan penting tiap konsep, sajian miskosnepsi, disertai argumentasi dan contoh fenomema konsep, dan disertai latihan konseptual (Ketut, 2016). Tippett (2010) menjelaskan bahwa teks sangkalan terdiri dari tiga komponen yaitu kalimat miskonsepsi, isyarat sanggahan (refutation cue), dan sanggahan dengan penjelasan ilmiah yang sesuai.

\section{METODE}

Penelitian ini merupakan penelitian kuasi eksperimen. Kelompok peserta dikelompokan berdasarkan kelasnya dan dipilih dengan random selection. Rancangan penelitian menggunakan pretestposttest non-equivalent control group design (Robson \& McCartan, 2016). Setiap kelompok diberikan pretest dan posttest untuk mengukur varibel dependen sebelum dan sesudah perlakuan.

Subjek penelitian dalam penelitian ini terdiri dari 136 siswa kelas X SMA. Dua guru fisika menjadi sukarelawan sebagai pengajar dalam penelitian ini. Pelajaran fisika di sekolah memiliki waktu 5 x 45 menit per periode tiap minggu. Peneliti dan guru melakukan diskusi terlebih dahulu cara menggunakan CCT dan RT sebelum diterapkan dikelas.

Terdapat 15 pertanyaan pilihan ganda yang diadopsi dari literatur (Ismail et al., 2015; Sencar \& Eryilmaz, 2004; Taşlidere, 2013) dan sisanya dikembangkan oleh peneliti. Tes terdiri dari 6 cakupan konsep, yaitu arus listrik, hambatan listrik, rangkaian seri \& paralel, ggl \& tegangan jepit, energi \& daya listrik, dan alat ukur listrik. Empat dosen ahli telah mereview instrumen untuk menilai validitas isi dari instrumen. Hasil review menyatakan butir tes cocok dengan tujuan penelitian dan sesuai dengan ruang lingkup konsep yang diteliti. Uji coba tes telah dilakukan pada siswa dan diperoleh nilai reabilitas 0,71 dengan menggunakan persamaan Sperman-Brown. Data dianalisis dengan bantuan software IBM SPSS 24.

Jawaban pilihan ganda dikategorikan menjdi benar dan salah, alasan jawaban dikategorikan ilmiah dan tidak ilmiah, sedangkan tingkat keyakinan siswa dikategorikan yakin (jika > 3) dan tidak yakin (jika < 3). Kombinasi dari jawaban, alasan dan tingkat keyakinan siswa kemudian dikategorikan menjadi 3 konsepsi (Tabel 1) yaitu Menguasai Konsep (MK), Miskonsepsi (M), dan Tidak Menguasai Konsep (TM).

Tabel 1. Kategori Konsepsi Siswa

\begin{tabular}{ll}
\hline $\begin{array}{l}\text { Kategori } \\
\text { Konsepsi }\end{array}$ & Tipe Respon Siswa \\
\hline $\begin{array}{l}\text { Menguasai } \\
\text { Konsep }\end{array}$ & Jawaban benar, alasan ilmiah, yakin \\
\hline Miskonsepsi & $\begin{array}{l}\text { jawaban benar, tidak ilmiah, yakin } \\
\text { jawaban salah, ilmiah, yakin } \\
\text { jawaban salah, tidak ilmiah, yakin }\end{array}$ \\
\hline Tidak & jawaban benar, ilmiah, tidak yakin \\
\hline
\end{tabular}

\begin{tabular}{ll}
\hline $\begin{array}{l}\text { Kategori } \\
\text { Konsepsi }\end{array}$ & Tipe Respon Siswa \\
\hline $\begin{array}{l}\text { Menguasai } \\
\text { Konsep }\end{array}$ & $\begin{array}{l}\text { jawaban salah, ilmiah, tidak yakin } \\
\text { jawaban benar, tidak ilmiah, tidak yakin } \\
\text { jawaban salah, tidak ilmiah, tidak yakin }\end{array}$ \\
\hline
\end{tabular}

(Sumber: Arslan, Cigdemoglu, and Moseley (2012))

Teks yang digunakan telah direview oleh 2 dosen ahli. Teks dibangun berdasarkan 6 area konsep pada listrik dinamis. Struktur teks CCT mengikuti struktur yang dikembangkan oleh Ozkan and Selcuk (2015). Struktur teks sangkalan sesuai struktur yang dikembangkan oleh Tippett (2010).

\section{HASIL DAN PEMBAHASAN Konsepsi Siswa}

Terdapat beragam konsepsi siswa yang terjadi, dan digolongkan menjadi tiga katagori konsepsi; menguasai konsep (MK), miskonsepsi (M) dan tidak menguasai konsep (TM). Deskripsi konsepsi siswa berdasarkan sub-materi listrik dinamis disajikan pada Tabel 2.

\section{Tabel 2. Persentase Konsepsi Awal Siswa}

\begin{tabular}{lllll}
\hline \multirow{2}{*}{ No. } & \multirow{2}{*}{ Konsep } & \multicolumn{3}{l}{ Konsepsi (\%) } \\
\cline { 3 - 5 } & & MK & M & TM \\
\hline 1 & arus listrik & 32,4 & 50,6 & 17,1 \\
2 & hambatan listrik & 29,6 & 46,7 & 23,7 \\
3 & rangkaian seri \& paralel & 23,8 & 49,1 & 27,1 \\
4 & ggl \& tegangan jepit & 20,6 & 33,8 & 45,6 \\
5 & energi \& daya listrik & 20,6 & 49,5 & 29,9 \\
6 & alat ukur listrik & 16,2 & 61,8 & 22,1 \\
\hline Rata-rata & 23,8 & 48,6 & 27,6 \\
\hline
\end{tabular}

Tabel 3. Hasil Box's M Test

\begin{tabular}{ll}
\hline Box's $\boldsymbol{M}$ & $\mathbf{1 2 , 7 5 4}$ \\
\hline$F$ & 2,079 \\
$d f 1$ & 6 \\
$d f 2$ & 439610,666 \\
Sig. & 0,052 \\
\hline
\end{tabular}

Tabel 4. Hasil Levene's Test

\begin{tabular}{lllll}
\hline & $\boldsymbol{F}$ & df1 & df2 & Sig. \\
\hline Penguasaan Konsep & 0,776 & 2 & 133 & 0,462 \\
Penurunan Miskonsepsi & 1,180 & 2 & 133 & 0,311 \\
\hline
\end{tabular}

Sebanyak 48,6\% siswa mengalami miskonsepsi dan $27,6 \%$ tidak menguasai konsep. Hanya 23,8\% saja yang menguasai konsep Listrik Dinamis. Ini menunjukkan sebagian besar konsepsi siswa adalah miskonsepsi.

Uji prasyarat yaitu (1) uji normalitas menunjukkan bahwa kelompok yang belajar terdistribusi normal, (2) uji homogenitas data dengan Levene's Test menunjukkan data homogen, dan (3) uji interkorelasi dengan product moment menunjukkan antar variable tidak terjadi kolinieritas. Berdasarkan uji prasyarat tersebut, dapat 
dikatakan bahwa persyaratan untuk melakukan pengujian hipotesis dengan MANCOVA telah terpenuhi.

Analisis MANCOVA menampilkan hasil analisis Varians-Kovarians dengan menggunakan Box's M Test (Tabel 3) dan Levene's Test (Tabel 4). Kedua variabel (penguasaan konsep dan penurunan miskonsepsi) secara bersama-sama dianalisis untuk mengetahui apakah memiliki matrik varians-kovarians yang sama pada tiap kelompoknya.

Hasil pengujian homogenitas kovarian dengen Box's $M$ Test diperoleh nilai sebesar 12,754 dengan nilai signifikansi sebesar 0,052. Jadi dapat diartikan bahwa variabel dependen (penguasaan konsep dan penurunan miskonsepsi) mempunyai matriks kovarians yang sama. Hasil pengujian homogenitas varians dengan Levene's Test memiliki nilai signifikansi lebih besar daripada 0,05 , maka varians variabel dependen untuk tiap kelompok belajar yang diteliti homogen.

\section{Pengaruh Struktur terhadap Penguasaan Konsep dan Penurunan Miskonsepsi}

Hasil analisis Wilks' Lambda pada uji

MANCOVA ditunjukan pada Tabel 5. Nilai signifikansi hasil pengujian diperoleh kurang dari 0,05. Jadi, terdapat perbedaan penguasaan konsep dan penurunan miskonsepsi pada materi Listrik Dinamis antara kelompok siswa yang belajar dengan struktur teks perubahan konseptual, teks sangkalan, dan teks konvensional dengan mengontrol pengetahuan awal siswa.

Secara deskriptif (Tabel 6) kelompok siswa yang belajar dengan struktur RT memiliki rata-rata penguasaan konsep $(11,02)$ lebih tinggi dari kelompok siswa yang belajar dengan struktur CCT dan ET, namun memiliki skor penurunan miskonsepsi $(5,80)$ lebih kecil dari kelompok siswa yang belajar dengan struktur CCT dan lebih besar dari siswa yang belajar dengan struktur ET.

Kelompok siswa yang belajar dengan Struktur CCT memiliki rata-rata skor penurunan miskonsepsi $(6,60)$ lebih besar dari kelompok siswa yang belajar dengan struktur RT dan ET, namun memiliki nilai ratarata penguasaan konsep lebih kecil dari kelompok siswa yang belajar dengan struktur RT dan lebih besar daripada kelompok yang belajar dengan struktur ET. Berdasarkan hasil tersebut, secara deskriptif struktur CCT maupun RT lebih unggul dalam meningkatkan penguasaan konsep dan penurunan miskonsepsi daripada teks struktur ET.

Lebih unggulnya hasil penguasaan konsep dan penurunan miskonsepsi siswa yang dibelajarkan dengan struktur teks perubahan konseptual (CCT) ataupun teks sangkalan (RT) dibandingkan dengan teks konvensional (ET), karena adanya kelebihan yang dimiliki oleh struktur teks perubahan konseptual dan teks sangkalan. Salah satu keunggulan dari struktur teks ini adalah memberikan kesempatan kepada siswa untuk menkonstruksi konsepsinya melalui konflik kognitif yang ditimbulkan dalam belajar menggunakan teks tersebut.

Struktur CCT maupun RT merupakan penyusunan materi pelajaran yang dikembangkan dari model pembelajaran perubahan konseptual. Melalui model ini, konsepsi awal dan miskonsepsi yang dimiliki oleh siswa dapat diketahui, sehingga dapat tanggulangi atau dibenahi untuk mencapai penguasaan konsep. Apabila siswa telah mampu menemukan sendiri konsepsinya, siswa akan mendapat suatu kepuasan intelektual yang datang dari dalam dirinya sendiri dan hal ini dapat menigkatkan keyakinan dirinya dalam belajar.

Tabel 5. Hasil Multivariate Tests

\begin{tabular}{lccc}
\hline Effect & Wilks & & \\
\hline Intercept & Lambda & $\boldsymbol{F}$ & Sig. \\
Pengetahuan awal & 0,208 & 249,221 & 0,000 \\
Struktur teks & 0,934 & 4,663 & 0,011 \\
\hline
\end{tabular}

Tabel 6. Hasil Descriptive Analysis

\begin{tabular}{llclr}
\hline & $\begin{array}{l}\text { Struktur } \\
\text { Teks }\end{array}$ & Mean & $\begin{array}{l}\text { Std. } \\
\text { Deviation }\end{array}$ & $\boldsymbol{N}$ \\
\hline Penguasaan & CCT & 10,71 & 1,646 & 45 \\
Konsep & RT & 11,02 & 1,903 & 46 \\
& ET & 9,49 & 1,984 & 45 \\
\hline Penurunan & CCT & 6,71 & 3,217 & 45 \\
Miskonsepsi & RT & 5,83 & 3,206 & 46 \\
& ET & 4,67 & 2,654 & 45 \\
\hline
\end{tabular}

Tabel 7. Hasil Tests of Between-Subjects Effects

\begin{tabular}{|c|c|c|c|c|c|c|}
\hline Source & Dependent Variable & Type III Sum of Squares & $d f$ & Mean Square & $F$ & Sig. \\
\hline \multirow[t]{2}{*}{ Corrected Model } & Penguasaan Konsep & 88,545 & 3 & 29,515 & 9,137 & 0,000 \\
\hline & Penurunan Miskonsepsi & 99,625 & 3 & 33,208 & 3,585 & 0,016 \\
\hline \multirow[t]{2}{*}{ Intercept } & Penguasaan Konsep & 1360,474 & 1 & 1360,474 & 421,164 & 0,000 \\
\hline & Penurunan Miskonsepsi & 635,649 & 1 & 635,649 & 68,615 & 0,000 \\
\hline \multirow[t]{2}{*}{ Pengetahuan Awal } & Penguasaan Konsep & 29,071 & 1 & 29,071 & 9,000 & 0,003 \\
\hline & Penurunan Miskonsepsi & 5,008 & 1 & 5,008 & 0,541 & 0,463 \\
\hline \multirow[t]{2}{*}{ Struktur Teks } & Penguasaan Konsep & 50,329 & 2 & 25,165 & 7,790 & 0,001 \\
\hline & Penurunan Miskonsepsi & 94,514 & 2 & 47,257 & 5,101 & 0,007 \\
\hline \multirow[t]{2}{*}{ Error } & Penguasaan Konsep & 426,396 & 132 & 3,230 & & \\
\hline & Penurunan Miskonsepsi & 1222,845 & 132 & 9,264 & & \\
\hline \multirow[t]{2}{*}{ Total } & Penguasaan Konsep & 15258,000 & 136 & & & \\
\hline & Penurunan Miskonsepsi & 5796,000 & 136 & & & \\
\hline \multirow[t]{2}{*}{ Corrected Total } & Penguasaan Konsep & 514,941 & 135 & & & \\
\hline & Penurunan Miskonsepsi & 1322,471 & 135 & & & \\
\hline
\end{tabular}




\section{Penguasaan Konsep Siswa}

Berdasarkan hasil pada Tabel 7, pengaruh utama yaitu struktur teks terhadap penguasaan konsep siswa diperoleh sebesar $F=9,137$ dengan $p<0,05$. Hasil tersebut menunjukkan bahwa terdapat perbedaan Penguasaan Konsep siswa antara kelompok siswa yang belajar dengan struktur teks perubahan konseptual, teks sangkalan, dan teks konvesional. Uji ANOVA pada penguasaan konsep siswa menunjukkan hasil yang signifikan, $\mathrm{F}=7,790$ dengan $p<0,05$. Jadi, struktur CCT ataupun RT memberikan penguasaan konsep lebih baik dibandingkan dengan struktur ET. Selain itu, ditunjukkan pula variabel pengetahuan awal siswa yang telah dikontrol secara statistik, pengaruh pengetahuan awal siswa menunjukkan hasil yang signifikan $(\mathrm{F}=9,000$ dengan $p<0,05)$.

Tabel 8. Hasil Pairwise Comparisons

\begin{tabular}{|c|c|c|c|c|}
\hline $\begin{array}{l}\text { Dependent } \\
\text { Variable }\end{array}$ & $\begin{array}{l}\text { (I) }-(\mathrm{J}) \\
\text { Struktur } \\
\text { Teks }\end{array}$ & $\begin{array}{l}\text { Mean } \\
\text { Difference (I- } \\
J)\end{array}$ & $\begin{array}{l}\text { Std. } \\
\text { Error }\end{array}$ & Sig. \\
\hline \multirow{3}{*}{$\begin{array}{l}\text { Penguasaan } \\
\text { Konsep }\end{array}$} & RT-CCT & 0,093 & 0,384 & 0,809 \\
\hline & CCT-ET & 1,249 & 0,379 & 0,001 \\
\hline & RT-ET & 1,342 & 0,382 & 0,001 \\
\hline \multirow{3}{*}{$\begin{array}{l}\text { Penurunan } \\
\text { Miskonsepsi }\end{array}$} & RT-CCT & 0,795 & 0,650 & 0,224 \\
\hline & CCT-ET & 2,033 & 0,642 & 0,002 \\
\hline & RT-ET & 1,239 & 0,647 & 0,058 \\
\hline
\end{tabular}

Uji lanjutan menunjukkan tiga perbandingan penguasaan konsep berdasarkan perlakuan yang diberikan (Tabel 8). (1) Perbedaan rata-rata skor penguasaan konsep untuk kelompok yang belajar dengan CCT dan RT adalah $\Delta \mu=0,093$ dengan $p>0,05$. Hasil tersebut menunjukkan penguasaan konsep siswa kelompok belajar dengan struktur CCT tidak jauh berbeda dengan kelompok belajar dengan struktur RT. (2) Perbedaan rata-rata skor penguasaan konsep untuk kelompok yang belajar dengan CCT dan ET adalah $\Delta \mu=$ 1,249 dengan $p<0,05$. Hasil tersebut menunjukkan penguasaan konsep siswa kelompok belajar dengan struktur CCT lebih baik dibandingkan dengan kelompok belajar dengan struktur ET. (3) Perbedaan rata-rata skor penguasaan konsep untuk kelompok yang belajar dengan RT dan ET adalah $\Delta \mu=1,342$ dengan $p<0,05$. Hasil tersebut menunjukkan penguasaan konsep siswa kelompok belajar dengan struktur RT lebih baik dibandingkan dengan kelompok belajar dengan struktur ET.

Jadi, secara keseluruhan skor rata-rata penguasaan konsep siswa kelompok yang belajar dengan struktur CCT maupun RT lebih baik daripada kelompok yang belajar dengan struktur ET. Skor rata-rata penguasaan konsep siswa kelompok belajar dengan struktur CCT dan RT tidak berbeda secara signifikan.

Penggunaan teks dengan struktur teks sangkalan (RT) pada pembelajaran fisika efektif dalam meningkatkan penguasaan konsep siswa (Ketut, 2016).
Struktur teks sangkalan ini menyajikan konsep-konsep ilmiah yang harus dikuasai oleh siswa dan miskonsepsi yang harus dihindari oleh siswa. Dengan disajikannya konsep-konsep yang harus dikuasai, siswa dapat dengan mudah membedakan konsep yang benar. Oleh karena itu, siswa yang belajar dengan teks RT secara langsung dapat mempelajari konsep-konsep ilmiah tersebut dan lebih mudah untuk membedakan konsepsi yang merupakan konsep ilmiah, sehingga penguasaan konsep siswa lebih tinggi dibandingkan kelompok yang belajar dengan struktur CCT maupun ET.

Akpınar and Tan (2011) menyampaikan teks perubahan konseptual lebih efektif daripada teks konvensional (ekspositori) dalam menata kembali skema konseptual siswa tentang kesalahpahaman (miskonsepsi) suatu konsep. Pada struktur teks perubahan konseptual (CCT) ini, siswa dituntut untuk dapat memformulasikan konsepsinya sendiri dari suatu peristiwa dan kemudian konsepsi ini dibandingkan dengan konsep ilmiah, sehingga terjadi konflik kognitif. Konflik kognitif ini dapat mengarahkan konsepsi siswa menjadi penguasaan konsep.

\section{Penurunan Miskonsepsi Siswa}

Berdasarkan hasil pada Tabel 7, pengaruh utama yaitu struktur teks terhadap penurunan miskonsepsi siswa diperoleh sebesar $F=3,585$ dengan $p<0,05$. Hasil tersebut menunjukkan bahwa terdapat perbedaan Penurunan Miskonsepsi siswa antara kelompok siswa yang belajar dengan struktur teks perubahan konseptual, teks sangkalan, dan teks konvesional. Uji ANOVA pada penurunan miskonsepsi siswa menunjukkan hasil yang signifikan, $\mathrm{F}=5,101$ dengan $p<0,05$. Jadi, struktur CCT ataupun RT memberikan penguasaan konsep lebih baik dibandingkan dengan struktur teks konvensional. Pengetahuan awal siswa telah dikontrol secara statistik. Pengaruh pengetahuan awal siswa menunjukkan hasil yang tidak signifikan dalam penurunan miskonsepsi $(\mathrm{F}=$ $0,541$ dengan $p>0,05)$.

Sama halnya pada penguasaan konsep, uji lanjutan untuk penurunan miskonsepsi diperoleh tiga perbandingan penurunan miskonsepsi berdasarkan perlakuan yang diberikan (Tabel 8). (1) Perbedaan ratarata skor penguasaan konsep untuk kelompok yang belajar dengan CCT dan RT adalah $\Delta \mu=0,795$ dengan $p>0,05$. Hasil tersebut menunjukkan penuruan miskonsepsi siswa kelompok belajar dengan struktur CCT tidak jauh berbeda dengan kelompok belajar dengan struktur RT. (2) Perbedaan rata-rata skor penguasaan konsep untuk kelompok yang belajar dengan CCT dan ET adalah $\Delta \mu=2,033$ dengan $p<0,05$. Hasil tersebut menunjukkan penurunan miskonspsi siswa kelompok belajar dengan struktur CCT lebih baik dibandingkan dengan kelompok belajar dengan struktur ET. (3) Perbedaan rata-rata skor penurunan miskonspsi untuk kelompok yang belajar dengan RT dan ET adalah $\Delta \mu=$ 1,239 dengan $p>0,05$. Hasil tersebut menunjukkan penguasaan konsep siswa kelompok belajar dengan 
struktur RT tidak berbeda secara signifikan dengan struktur ET.

Jadi, skor rata-rata penurunan miskonsepsi siswa kelompok yang belajar dengan struktur teks perubahan konseptual lebih baik daripada kelompok yang belajar dengan struktur teks sangkalan pada taraf signifikansi 0,05. Skor rata-rata penurunan miskonsepsi siswa kelompok yang belajar dengan struktur teks perubahan konseptual dan teks sangkalan tidak berbeda secara signifikan. Skor rata-rata penurunan miskonsepsi siswa kelompok yang belajar dengan struktur teks sangkalan dan teks konvensional tidak berbeda secara signifikan.

Penggunaan CCT dalam memperbaiki konsepsi siswa lebih efektif daripada metode pengajaran konvensional Aydin (2012). Menurut Posner et al. (1982) dalam penerapannya CCT memiliki empat kondisi yang harus dipenuhi, yaitu dissatisfaction (ketidakpuasan dengan konsepsi yang ada), intelligible (kejelasan konsep), plausible (dapat dipercaya), dan fruitful (kebermanfaatan konsep). Dengan dipenuhinya kondisi tersebut siswa akan mudah mempelajari materi dan penurunan miskonsepsi semakin besar. Dipihak lain, Sinatra and Broughton (2011) menyampaikan bahwa teks sangklan (RT) dapat membenahi miskonsepsi yang terjadi pada siswa. Tippett (2010) juga menjelaskan bahwa dengan membaca RT dapat mengarahkan siswa pada perubahan konseptual dan membaca teks dengan struktur RT lebih menarik daripada teks konvensional (ET) yang cenderung dapat mengarahkan siswa ke dalam miskonsepsi.

Penelitian ini memiliki kebaharuan, karena belum terdapat penelitian yang membandingkan ketiga struktur teks secara bersama-sama. Penelitian ini dapat memperlihatkan perbedaan proses penguasaan konsep dan miskonsepsi siswa dari struktur RT dan CCT dibandingkan dengan hanya meggunakan teks konvensional dengan struktur expositori dalam pembelajaran.

Ruang lingkup yang terbatas menyebabkan penelitian hanya dapat menggambarkan penguasaan konsep dan miskonsepsi siswa pada satu sekolah dan pada satu materi pokok bahasan saja, namun hasil yang diperoleh, dapat memberikan gambaran yang memadai tentang penguasaan konsep dan miskonsepsi siswa dari tiga struktur teks yang berbeda. Pada penelitian lanjutan, diharapkan dapat dilaksanakan dengan ruang lingkup penelitian yang lebih luas dan materi pelajaran yang lebih beragam.

\section{PENUTUP Simpulan}

Pada penelitian ini seluruh kelompok eksperimen mengalami peningkatan penguasaan konsep dan penurunan miskonsepsi. Berdasarkan hasil analisis, penggunaan struktur teks dengan bentuk RT menunjukkan hasil yang lebih baik dalam meningkatkan penguasaan konsep siswa dan penggunaan struktur teks dengan bentuk CCT lebih baik dalam penurunan miskonsepsi siswa. Penelitian lain yang terkait sejauh ini juga memperlihatkan hasil yang sama dengan penelitian ini.

\section{Saran dan Rekomendasi}

Guna meningkatkan kualitas pembelajaran kedepannya, peneliti menyarankan guru ataupun peneliti harus mampu menumbuhkan minat baca siswa baik melalui motivasi maupun melalui pengemasan teks yang menarik bagi siswa. Selain itu, sebelum menggunakan teks yang dikemas dengan struktur teks RT dan CCT dalam proses pembelajaran, direkomendasikan untuk dilakukan uji validitas isi dan disainnya oleh ahli. Banyak faktor yang perlu diperhatikan dalam pengemasan materi dalam struktur RT maupun struktur CCT yaitu isi, tata bahasa, tata tulis, dan desain. Kedua, siswa harus memiliki minat baca agar teks yang digunakan dapat berperan optimal. Oleh karena itu, guru ataupun peneliti harus mampu menumbuhkan minat baca siswa baik melalui motivasi maupun melalui pengemasan teks yang menarik bagi siswa.

\section{UCAPAN TERIMA KASIH}

Terima kasih peneliti ucapkan kepada SMAN 1 Banjarangkan yang telah memberikan fasilitas bagi peneliti dan kepada Kemenristekdikti yang telah mendanai penelitian ini melalui Dana Penelitian Skim Hibah Pascasarjana DRPM Kemenristekdikti.

\section{DAFTAR PUSTAKA}

Akpinar, M., \& Tan, M. (2011). Developing, implementing, and testing a conceptual change text about relativity. Western Anatolia Journal of Educational Sciences.

Arslan, H. O., Cigdemoglu, C., \& Moseley, C. (2012). A three-tier diagnostic test to assess pre-service teachers' misconceptions about global warming, greenhouse effect, ozone layer depletion, and acid rain. International Journal of Science Education, 34(11), 1667-1686.

Aydin, S. (2012). Remediation of misconceptions about geometric optics using conceptual change texts. Journal of Education Research and Behavioral Sciences, 1(1), 001-012.

Cordova, J. R., Sinatra, G. M., Jones, S. H., Taasoobshirazi, G., \& Lombardi, D. (2014). Confidence in prior knowledge, self-efficacy, interest and prior knowledge: Influences on conceptual change. Contemporary Educational Psychology, 39(2), 164-174.

Gurel, D. K., \& Eryilmaz, A. (2013). A content analysis of physics textbooks as a probable source of misconceptions in geometric optics. Hacettepe Üniversitesi Eğitim Fakültesi Dergisi, 28(28-2). 
Guzzetti, B. J., Snyder, T. E., \& Glass, G. V. (1992). Promoting conceptual change in science: Can texts be used effectively? Journal of reading, 35(8), 642-649.

Ismail, I. I., Samsudin, A., Suhendi, E., \& Kaniawati, I. (2015). Diagnostik miskonsepsi melalui listrik dinamis four tier test. Prosiding Simposium Nasional Inovasi dan Pembelajaran Sains, Bandung, 8-9.

Ketut, S. I. (2016). Pengaruh Teks Sangkalan Terhadap Pencapaian Konsep Siswa Tentang Hukum Pertama dan Ketiga Newton. JPI (Jurnal Pendidikan Indonesia), 5(1), 69-81.

Ozkan, G., \& Selcuk, G. S. (2015). Effect of Technology Enhanced Conceptual Change Texts on Students' Understanding of Buoyant Force. Universal Journal of Educational Research, 3(12), 981-988.

Perdana, G. P. (2017). Pengetahuan Awal dan Tingkat Keyakinan Siswa Tentang Konsep Listrik Dinamis. Jurnal Imiah Pendidikan dan Pembelajaran, 1(2).

Posner, G. J., Strike, K. A., Hewson, P. W., \& Gertzog, W. A. (1982). Accommodation of a scientific conception: Toward a theory of conceptual change. Science education, 66(2), 211-227.

Robson, C., \& McCartan, K. (2016). Real world research: John Wiley \& Sons.

Sencar, S., \& Eryilmaz, A. (2004). Factors mediating the effect of gender on ninth-grade Turkish students' misconceptions concerning electric circuits. Journal of Research in Science Teaching: The Official Journal of the National Association for Research in Science Teaching, 41(6), 603-616.

Sinatra, G. M., \& Broughton, S. H. (2011). Bridging reading comprehension and conceptual change in science education: The promise of refutation text. Reading Research Quarterly, 46(4), 374393.

Taşlıdere, E. (2013). Effect of conceptual change oriented instruction on students' conceptual understanding and decreasing their misconceptions in DC electric circuits. Creative Education, 4(4), 273-282.

Tippett, C. D. (2010). Refutation text in science education: A review of two decades of research. International Journal of Science and Mathematics Education, 8(6), 951-970.

Ültay, N., Durukan, Ü. G., \& Ültay, E. (2015). Evaluation of the effectiveness of conceptual change texts in the REACT strategy. Chemistry Education Research and Practice, 16(1), 22-38. 